"The impact of executive remuneration on risk-taking in the banking industry"

\begin{tabular}{|c|c|c|}
\hline AUTHORS & $\begin{array}{l}\text { Ezelda Swanepol } \\
\text { Anet Magdalena Smit }\end{array}$ & \\
\hline ARTICLE INFO & \multicolumn{2}{|c|}{$\begin{array}{l}\text { Ezelda Swanepol and Anet Magdalena Smit (2016). The impact of executive } \\
\text { remuneration on risk-taking in the banking industry. Investment Management and } \\
\text { Financial Innovations, 13(3), 110-117. doi:10.21511/imfi.13(3).2016.10 }\end{array}$} \\
\hline DOI & \multicolumn{2}{|c|}{ http://dx.doi.org/10.21511/imfi.13(3).2016.10 } \\
\hline RELEASED ON & \multicolumn{2}{|l|}{ Tuesday, 23 August 2016} \\
\hline JOURNAL & \multicolumn{2}{|c|}{ "Investment Management and Financial Innovations" } \\
\hline FOUNDER & \multicolumn{2}{|c|}{ LLC "Consulting Publishing Company "Business Perspectives" } \\
\hline \multirow{2}{*}{ NUMBER OF REFERENCES } & & $\begin{array}{l}\text { E: } \\
\text { E=E }\end{array}$ \\
\hline & NUMBER OF FIGURES & NUMBER OF TABLES \\
\hline 0 & 0 & 0 \\
\hline
\end{tabular}

(C) The author(s) 2022. This publication is an open access article. 
Ezelda Swanepoel (South Africa), Anet Magdalena Smit (South Africa)

\title{
The impact of executive remuneration on risk-taking in the banking industry
}

\begin{abstract}
In the aftermath of the credit crisis of 2007-2009, there was considerable public frustration with regard to executive remuneration, particularly in the banking industry. Consequently, the need for regulated remuneration practices became essential. For this purpose, the Prudential Regulation Authority (PRA) aims to align risk and reward by encouraging good risk management and discouraging excessive risk-taking. This paper aims to demonstrate the correlation between the health of the banking industry and economic activity, as well as the change in executive remuneration pre and post the credit crisis. In addition, the paper aims to measure the correlation between executive remuneration in the form of cash and equity, and risk-taking. The unique features of banking emphasized the interconnectedness to the broader economy. The statistical package for social sciences (SPSS) was used to perform these analyses. It was found that as executive remuneration in the form of cash increased, risk-taking decreased. In addition, as executive remuneration in the form of equity decreased, risk-taking increased. In summary, the research points to the fact that executives have in fact been remunerated in terms of equity. However, the results indicate that this may not have enticed the executives to take on more risks.
\end{abstract}

Keywords: credit crisis, executive remuneration, banking industry, Prudential Regulating Authority, risk management, excessive risk-taking, equity.

JEL Classification: C21, G01, G21, G32.

\section{Introduction}

It is indicated in literature that excessive risk-taking in the banking industry, along with slack regulatory supervision, have had dire economic consequences (Keeley, 1990; Merrouche \& Nier, 2010). This resulted in the credit crisis of 2007-2009, which was so detrimental that it has, in fact, been termed as the worst financial crisis since the Great Depression of 1929. The credit crisis is viewed by some as either a direct or indirect result of the repeal of the Glass Steagall Act, which saw the enactment of the Gramm-Leach-Bliley Act (GLBA), an advocate for relaxed regulation (Crawford, 2011).

The GLBA of 1999 has been purported to be the key factor behind consolidation in the banking industry. This act permitted commercial banks in the United States (US) to diversify into non-traditional activities, and facilitated mergers with institutions that engage in capital market activities and insurance underwriting. As a result, over the past two decades, successive merger waves changed the face of US banking by giving rise to banks that are larger and engage in a broader range of financial activities (Hagendorff \& Vallascas, 2011).

This Act was responsible for bank deregulation, which allowed for sharp increases in the share of equity-based executive compensation in the banking industry (Cunat \& Guadalupe, 2009). The use of stock options in executive compensation became so

(c) Ezelda Swanepoel, Anet Magdalena Smit, 2016.

Ezelda Swanepoel, M.Com., Lecturer, School of Economic Sciences, North-West University, South Africa.

Anet Magdalena Smit, Ph.D., Associate Professor, NWU School of Business and Governance, North-West University, South Africa. widespread over the last decade that the contractual risk-taking incentives for executives at large US banks were higher than at non-financial institutions (DeYoung, Pemg \& Yan, 2010). Furthermore, it is widely believed that the use of incentive pay in banking-motivated risk-taking was a contributory factor to the recent credit crisis of 2007-2009. Bolton, Mehran and Shapiro (2015) argued that executive remuneration should be linked to debt and should be tied to the bank's credit default swaps. However, this argument does not form part of this particular research.

The possible motivation for increased risk-taking as a result of share equity-based compensation can be attributed to two factors. Firstly, deregulation expanded managerial discretion over the scale and scope of banking activities, and performance contracts became more equity-based in order to encourage bank executives to take advantage of such growing investment opportunities (Raviv \& Sisli-Ciamarra, 2013). Secondly, incentive-based compensation in banking is designed to shift risk from bank shareholders to regulators and bond holders. Since banks are highly leveraged institutions, shareholders benefit from higher risk investment choices, which increase the potential value of bank assets, while keeping the downside risk limited (Armstrong, Larcker, Ormazabal \& Taylor, 2013).

Conversely, there are numerous examples of studies (Angeli \& Gitay, 2015; Jensen \& Meckling, 1976; Rego \& Wilson, 2012; Smith \& Stulz, 1985), which advocate equity remuneration for executives. The reasoning for this is that if executives had actual shares in the bank, they would be persuaded to take 
on less risk, as they would be of the opinion that the risk would be reverted to the executives and not to the regulators.

The study contributes to the literature in various ways. Firstly, it highlights the effectiveness of the $\mathrm{Z}$-score as a predictor of large bank risk-taking which could be relevant to external shareholders. As the public is most affected by banking behavior, as a result of it being so interlinked with the economy, and they do not fully understand the functioning of the banking industry, they will by no means accept risky behavior by banks. Secondly, it improves the understanding of the manner in which bank executives are remunerated, and contradicts current theory as to the manner in which risk-taking is affected by executive remuneration in the form of equity holdings. Finally, this paper briefly notes that executive remuneration should be linked to debt and it should be tied to the bank's credit default swaps, hence, a different manner in which remuneration can be calculated, which might lead to lower risktaking.

The research is structured as follows: a literature review, detailing various controversies with regard to bankers' remuneration is provided in section 1 . The correlation between executive incentives, risktaking and sustainability is detailed in section 2 . The methodology used is indicated in section 3 , while the results are presented and discussed in section 4 . A conclusion follows in final section.

\section{Literature review}

Zalewska (2015) stated that until recently, there was little in corporate governance literature that focused exclusively on banking and bankers' remuneration, although the unique features of market failure surrounding banking were commonly mentioned and, in particular, the cost that banks may inflict on third parties as a result of transaction costs, which are particularly high. Consequently, the specific features of banking point to a remuneration debate, based solely on the separation of ownership, and control is rarely mentioned, which may, therefore, lead to incorrect conclusions and harmful solutions.

1.1. The principal-agent theory. This theory pertains to the separation of ownership and control, and initiated the debate on the mitigation of problems that arise due to principals and agents hired by them who may have different objectives, resulting in the principals not fully observing the actions undertaken by agents (Salehyan, Sirokey \& Wood, 2014). Consequently, the manner in which differences in objectives and their effects are minimized, so as to limit asymmetries of information between agents and principals, has become a key strand in governance literature (Smith, Rotolo \& Sartor, 2013).

Conflict of interest between an institution's shareholders and the executive directors is assumed in this theory. Executive directors acting as agents are hired to make decisions that will maximize shareholder wealth. However, as agents they may be tempted to maximize their own wealth (Angeli \& Gitay, 2015). Therefore, taking on more risks than the shareholders would permit, they stand to receive immediate gains, but will not be liable for any costs or losses that may subsequently occur for the institution and the shareholders. Shareholders may, therefore, wish to monitor executive directors' actions to ensure that it corresponds with their own risk appetite (Salehyan et al., 2014). As a result, the alignment of interests by making agents equityfocused is one of the most commonly postulated solutions (Smith et al., 2013). Executive remuneration has frequently been addressed by regulators and other policy-making bodies, with the majority of the literature focusing on the corporate governance structure of non-financial institutions. However, the credit crisis of 2007-2009 emphasized the importance of the financial sector, as well as the resulting consequences should it not adhere to current governance practices (Zalewska, 2015).

A solution to this dilemma would be to use variable remuneration in an attempt to better align executive directors' appetites to those of shareholders. Variable remuneration may, for instance, be awarded as equity, transferring a portion of the bank's ownership to its executive directors. This could increase long-term performance considerations in executive directors' decisionmaking (Angeli \& Gitay, 2015).

However, the emphasis on the unique features of banks and bankers' remuneration should not be understated. There are numerous different arguments as to why the principle-agent theory should not be utilized in the banking sector, hence, variable remuneration has been proposed and implemented as a possible solution or mitigation technique.

1.2. Bankers' remuneration. Zalewska (2015) argued that when discussing remuneration structures as a mechanism to resolve issues that arise from the separation of ownership and control, it is implicitly assumed that an institution is equity-financed and does not have any social or broadeconomy links and obligations. The banking sector does not comply with this standard approach. Two primary drivers for this are, firstly, banks' capital structure and, secondly, banks' interconnectivity and their systemic risk. 
With regard to banks' capital structures, a study conducted by Allen, Carletti and Marquez (2014) showed shareholders to be a relatively minor group in comparison with depositors and other stakeholders. The second driver suggests that it is not sufficient to consider corporate governance on a bank-by-bank basis. In any banking sector, there is often a significant number of institutions that network closely with each other. Consequently, one bank's failure can affect the stability of the whole financial sector (Liu, Quiet \& Roth, 2015).

Furthermore, banks' services are deeply rooted in the economic activities of their countries. Even in the most advanced economies with the most developed stock markets, banks are fundamental providers of financing for economic and business activities (Leaven, Ratnovski \& Tong, 2014). Their roles in supporting and ensuring the economic development of countries are essential and, therefore, when the banking sector experiences difficulties, the whole of society bears the consequences. This was exactly the case in 2007, when world financial markets were in the midst of a recession termed the worst since the Great Depression of 1929 (Zalewska, 2015).

These unique features of the banking industry are emphasized particularly in banks' risk-taking and remuneration issues, when banks are systematically important ("too big to fail"), and when they are deeply interconnected (Liu et al., 2015). Given the complexity of the unique features of banks, regulation may be required to negotiate the strategic objectives of banks between shareholders and governments representing stakeholders (Afonso, Santos \& Traina, 2014).

1.3. Regulating remuneration. In the aftermath of the credit crisis of 2007-2009, there was considerable public frustration with regard to executive remuneration, particularly in the banking industry (Erkins, Hung \& Matos, 2012; Falenbrach \& Stulz, 2011). Consequently, the need for regulated remuneration practices became essential. For this purpose, the Prudential Regulation Authority (PRA) aims to align risk and reward by encouraging good risk management and discouraging excessive risk-taking. Accordingly, it is intended to contribute to a higher level of resilience within banks and, therefore, to support financial stability. In addition, effective competition within the banking sector and the labor market will determine the total levels of remuneration (Angeli \& Gitay, 2015).

During 2009, the Financial Stability Board (FSB) issued a report, "Principles and standards for sound compensation practices", which stipulated that variable remuneration schemes should be designed to work in concert with overall risk management (Ferrarini \& Ungureanu, 2012). The metrics determine that variable remuneration awards should provide signals of the institution's risk appetite, which in turn should translate into a given level of risk-taking by employees (Kregel, Kattel \& Tonveronachi, 2016). These metrics should be structured in such a manner that employee incentives are aligned with the long-term interests of the business, while taking into account the time frame over which financial risks crystallize (Angeli \& Gitay, 2015).

Furthermore, variable remuneration contributes to the flexibility of banks' staff cost bases. During times of stress, cost can be reduced to help to maintain the financial health of the institution. Variable remuneration can thus act as a form of loss-absorbing capacity for the financial system. The FSB also indicated that a substantial proportion of remuneration should be variable and paid on an individual, business unit, and institutional performance basis (Ferrarini \& Ungureanu, 2012; and Kregel et al., 2016).

\section{Executive incentives, risk-taking and sustainability}

During 2009, the Financial Stability Forum (FSF) published a report, which stated that "multiple surveys find that over $80 \%$ of market participants believe that compensation practices played a role in promoting the accumulation of risks that led to the 2008 crisis. Experts agree." (Financial Stability Forum, 2009). Given the events of 2007 and of the following year, there can be no doubt that excessive risk-taking had accumulated, but the question was whether this was exclusively due to the bankers accumulating risk, or whether their remuneration incentives were structured to result in exactly that.

In recent years, prior to the credit crisis of 20072009 , bonus payments had more than doubled in the financial and insurance industries. In addition, there was a broad consensus that banks' remuneration policies were a contributing factor to the crisis (Gregg et al., 2012). This included rewarding high short-term profits with generous variable remuneration awards through encouraging excessive risk-taking. Long-term risks resulting from such practices were not taken into consideration (Angeli \& Gitay, 2015).

Furthermore, one former Chair of the Financial Services Authority (FSA), highlighted the role that inappropriate incentive structures played in encouraging imprudent behavior (Falenbrach \& Stulz, 2011). Moreover, the Treasury Select Committee's report on the credit crisis of 2007-2009 
argued that the design of bonus schemes in the banking sector were flawed in too many cases, and not aligned with the interests of shareholders and the long-term sustainability of banks. As a result, the global regulatory response sought to align incentives with the level of risk-taking (Rego \& Wilson, 2012).

The credit crisis of 2007-2009 highlighted the importance of the financial sector's stability to the broader economy. It also prompted regulators to consider whether non-cash awards could be used as an effective manner in which to align risk-taking incentives. Prior to the credit crisis of 2007-2009, banks were able to award their bonuses as cash awards at year-end. However, since 2010, at least $50 \%$ of variable remuneration awards are required to be awarded in non-cash instruments such as shares or debt, which create incentives aligned with long-term value creation and the time horizons of risk (Angeli \& Gitay, 2015). Consequently, the following propositions can be formulated:

Proposition (1): The health of the banking sector has significant effects on overall economic activity.

Proposition (2): Executive remuneration paid in cash decreased, while executive incentives in the form of equity increased post the credit crisis.

Proposition (3): Executive remuneration in the form of cash has an impact on risk-taking in the banking sector.

Proposition (4): An increase in executive remuneration in the form of cash leads to an increase in risk-taking.

Proposition (5): Executive incentives in the form of equity have an impact on risk-taking in the banking sector.

Proposition (6): An increase in executive incentives in the form of equity value will lead to a decrease in risk-taking.

\section{Research methodology}

3.1. Stability. As a result of dire economic conditions, and possibly because executive remuneration incentives were structured in the way it was at the time, bank risk-taking took center stage for regulatory debate. This risk-taking can be measured by means of Z-scores developed by Boyd, Graham \& Hewitt (1993), De Nicolo (2000), Hannan \& Hanweck (1998), and Roy (1952). The Zscore is a measure of bank stability, which indicates the distance from insolvency. It combines the accounting measures of profitability, leverage and volatility. Specifically, insolvency can be defined as a state where losses surmount equity $(E>\pi)$, where $E$ is equity, and $\pi$ is profit. The probability of insolvency can be expressed as prob $(-R O A<$
$C A R$ ), where $R O A$ is return on assets, calculated as $\pi / A$ and $C A R$ is the capital-to-asset ratio, calculated as $E$ /A. Standard deviation is expressed as SD. If profits are assumed to follow a normal distribution, it can be proven that $\mathrm{Z}=(R O A+C A R) / S D(R O A)$, which is the inverse of the probability of insolvency(Tarraf \& Majeske, 2013). More specifically, the Z-score indicates the number of standard deviations that a bank's ROA has to fall below its expected value before equity is depleted and the bank becomes insolvent (Boyd et al., 1993; De Nicolo, 2000; Hannan \& Hanweck, 1998; and Roy, 1952).

Thus, a smaller z-score can be associated with narrow returns, larger return volatility or higher leverage (Mirzeai, 2013). Moreover, an increase in the capital-to-asset ratio would raise the Z-score, as would an increase in the operating return on assets. A Z-score can only be calculated if the accounting information for at least four years is available. Again, there are no set benchmarks for a Z-score. The Z-score merely indicates that a bank may benearing bankruptcy, should its Z-score continue to decrease (Tarraf \& Majeske, 2013).

3.1.1. Model diagnostics. As this model has been used extensively in literature, it is important to emphasize the relevance and importance thereof. One important and relevant study conducted by Chiaramonte, Croci and Poli (2015) confirmed that the Z-score was still very relevant and could even be compared to CAMELS (Capital, Asset Quality, Management Earnings, Liquidity, and Sensitivity to market risk) variables. This particular study focused on the empirical attractiveness of the Z-score, as it does not require strong assumptions about the distribution of ROA. In addition, Chiaramonte et al. (2015) examined whether the Z-score was an accurate tool to predict bank distress on a sample of banks from 12 European countries.

Based on the above research, it was found that the Z-score shows good predictive power to identify bank distress. Further to that, the key results indicated that the Z-score performed similarly to the CAMELS variables. It did, however, have the advantage of being more parsimonious than CAMELS models, as it demanded less accounting and questionable data. Such a result is valuable for stakeholders, as they rely solely on available public information and seek simple and reliable measures of bank soundness.

Moreover, these researchers found that the predictive ability of the Z-scores held, even when using a different computational approach, which took into account the average returns on assets over a three-year period. They also assessed the 
predictive power of the Z-score according to various bank characteristics and found that the Z-score was slightly more effective when the organizational and productive complexity of banks increased along with the public incentives to scrutinize bank riskiness, as it is the case for large banks. Finally, Chiaramonte et al. (2015) indicated that, during the financial crisis, the accuracy of the Z-score marginally improved with respect to the whole period.

3.2. Population, sample and data collection. This study comprises two samples, as a fully systematic test of banks' risk-taking would require data from all international banks affected by the credit crisis, and such a study is not feasible. Hence, the sample used to measure risk-taking in banks focused on the largest and most publicly announced banks, as they are marked as more important than smaller banks from an economic investment perspective. The sample includes six large international banks from the United Kingdom and the United States. The financial data obtained are publicly available, and the last eight years of data were analyzed (2007-2014).

3.3. Data analysis. The Z-scores for each individual bank, as well as the mean Z-scores were calculated, using Microsoft Excel as only basic descriptive statistical analyses were used. In order to test the propositions, different techniques were used. For the different propositions, the Statistical Package for Social Sciences (SPSS) was used to perform more advanced statistical analysis by means of correlation and analysis of variance (ANOVA) of cash remuneration, equity remuneration and Z-scores. One of the reasons for the frequency of regression of ANOVA applications is its suitability for many different types of study designs. ANOVA procedures are applicable to experimental, quasiexperimental and non-experimental data.

\section{Results and discussion}

4.1. Descriptive statistics. Two data sets are provided. The first data set provides the descriptive statistics between 2007 and 2010 (Table 1), as this is the period just prior to and during the crisis being officially declared by the National Bureau of Economic Research on 1 December 2008. The significance of this period is that, due to higher competition and dire economic conditions, risktaking would possibly have been high. The second data set provides the descriptive statistics between 2011 and 2014, as this is the period when it was required by banks to implement variable remuneration schemes in terms of increased equity. A comparison of the two periods will indicate if risk-taking is, in fact, affected by equity holdings of executives.

Table 2 provides the descriptive statistics for the analyzed variables for the period between 2011 and 2014 , a period just prior to and during the financial crisis, which signified low economic growth. For the purposes of this research only the mean of the base salaries (depicted in millions) and equity values (depicted in millions) was of value. This was to determine if base salaries and equity value had in fact changed post the credit crisis, and to determine if they had any effect on risk-taking during the same period.

The mean base salary was US $\$ 2.78$ million, with the mean share value at US $\$ 18.58$ million. The mean Z-score for the period was 1.76 , with a maximum of 4.2 , a minimum of -1.54 , and a standard deviation of 1.47. This indicates that there was volatility in the market, as some experienced a somewhat higher Z-score, while others had extremely high risk-taking practices. As mentioned, the Z-scores were calculated with the formula $(\mathrm{ROA}+\mathrm{CAR}) / \mathrm{SD}(\mathrm{ROA})$, where ROA is the return on assets, CAR is the capital asset ratio (Assets/Equity), and SD is the standard deviation.

Table 1. Descriptive statistics from 2007-2010

\begin{tabular}{|l|c|c|c|c|c|}
\hline & $\mathrm{N}$ & Minimum & Maximum & Mean & $\begin{array}{c}\text { Std. } \\
\text { deviation }\end{array}$ \\
\hline $\begin{array}{l}\text { Base salary } \\
\text { (US\$) }\end{array}$ & 16 & 1.54 & 3.88 & 2.78 & 0.77 \\
\hline $\begin{array}{l}\text { Share value } \\
\text { (US\$) }\end{array}$ & 16 & 0.02 & 51.85 & 18.58 & 20.53 \\
\hline Z-scores & 16 & -1.54 & 4.20 & 1.76 & 1.47 \\
\hline
\end{tabular}

Table 2 provides the descriptive statistics for the analyzed variables between 2011 and 2014. The mean base salary is indicated as US $\$ 3.13$ million, with the mean share value as US $\$ 10.85$ million. This indicates that although there had been regulatory practices and public scrutiny with regard to high banking executives' salaries and lucrative bonuses, they had actually increased. In addition, the mean US\$ value of equity holdings of executive staff decreased.

Furthermore, the mean Z-score for the period 20112014 was analyzed at 6.81 , with a minimum of -0.07 , a maximum of 13.99 , and a standard deviation of 4.98. This indicates that although the US\$ value of salaries for executives had increased, it did not have a negative effect on the Z-scores. In addition, from this data, it may be concluded that the decrease in equity holdings by executives also did no thave a negative effect on the Z-scores, hence, risk-taking. 
Table 2. Descriptive statistics from 2011 to 2014

\begin{tabular}{|l|c|c|c|c|c|}
\hline & $\mathrm{N}$ & Minimum & Maximum & Mean & $\begin{array}{c}\text { Std. } \\
\text { deviation }\end{array}$ \\
\hline $\begin{array}{l}\text { Base salary } \\
\text { (US\$) }\end{array}$ & 16 & 0.0012 & 11.17 & 3.13 & 2.72 \\
\hline $\begin{array}{l}\text { Share Value } \\
\text { (US\$) }\end{array}$ & 16 & 0.0043 & 49.58 & 10.85 & 15.41 \\
\hline Z-scores & 16 & -0.07 & 13.99 & 6.81 & 4.98 \\
\hline
\end{tabular}

4.2. Proposition testing results. Proposition (1): the health of the banking sector has significant effects on overall economic activity. In numerous studies conducted by Bernanke (1983), Kalemli-Ozcan et al. (2013), and Makinin (2014), it is indicated that the health of the banking sector does in fact have substantial effects not only on overall economic activity, but also on the size and persistence of economic cycles. In addition, as becomes evident from not only the dire repercussions of the credit crisis of 2007-2009, but also from the ominous circumstances most individuals in the US faced during the Great Depression of 1929, it is clear that sustainability in the banking industry was essential. Hence, Proposition (1) may be valid.

Proposition (2): executive remuneration paid in cash decreased, while executive incentives in the form of equity increased post the credit crisis. Table 1 and Table 2 provide descriptive statistics for the periods 2007-2010 and 2011-2014, respectively. From both these Tables it becomes evident that base salaries did, in fact, increase from 2007-2010 to 2011-2014. In addition, incentives in the form of equity decreased during the periods of 2007-2010 and 2011-2014. The Z-scores also increased during the periods of 20072010 and 2011-2014. However, from the descriptive statistics alone it could not be determined if the base salary and share values had any effect on the Z-scores. Hence, Proposition (2) may be valid.

Table 3 indicates the results of the testing of the remaining propositions. From the results it can be deducted that the independent variables (base salary and share value) depict $44.9 \%$ of the changes to the dependent variable, as the adjusted R-square is 0.449. In addition, the ANOVA Table indicates that the model was significant, which indicates that the changes in the dependent variable are significant to the independent variables with a sig. value of 0.00 . Further to this, the Beta values from the Coefficient Table are the regression equation $\left(\mathrm{B}_{0}=0.514 ; \mathrm{B}_{1}=\right.$ $\left.1.71 ; B_{3}=-8.62\right)$. The Standard Error for the Constant indicates that, at an $\alpha=0.05$ and degrees of freedom (df) of 2, the Beta of 0.514 falls between the range of -4.064 and 5.092. This was calculated with a critical value of 4.303 . Taking $\alpha=0.05$ with df of 2 and a critical value of 4.303 , this can be computed for all the variables.
The t-value is derived by dividing the Beta with the Standard Error. This value is used to determine if the data is statistically significant. However, the data analysis provided Sig. values, and with a Sig value $<0.05$, the data is statistically significant.

Table 3. Regression and ANOVA of Base Salary and Share Values on Z-scores

Model summary

\begin{tabular}{|c|c|c|c|c|}
\hline Model & $\mathrm{R}$ & R-square & Adjusted R-square & $\begin{array}{c}\text { Std. error of the } \\
\text { estimate }\end{array}$ \\
\hline 1 & $.696^{\mathrm{a}}$ & .485 & .449 & 3.29 \\
\hline
\end{tabular}

Notes: ${ }^{\text {a. }}$ Predictors: (Constant), Base Salary, Share Value.

ANOVA $^{\text {a }}$ (Analysis of Variance)

\begin{tabular}{|c|l|c|c|c|c|c|}
\hline \multicolumn{2}{|c|}{ Model } & Sum of squares & df & Mean square & $\mathrm{F}$ & Sig. \\
\hline \multirow{4}{*}{1} & Regression & 295.4 & 2 & 147.7 & 13.65 & $.000^{\mathrm{b}}$ \\
\cline { 2 - 7 } & Residual & 313.7 & 29 & 10.81 & & \\
\cline { 2 - 7 } & Total & 609.1 & 31 & & & \\
\hline
\end{tabular}

Notes: a. Dependent Variable: Z-scores. b. Predictors: (Constant), Base Salary, Share Value.

Coefficients

\begin{tabular}{|c|l|c|c|c|c|c|}
\hline \multicolumn{2}{|c|}{ Model } & \multicolumn{2}{|c|}{$\begin{array}{c}\text { Non-standardized } \\
\text { coefficients }\end{array}$} & $\begin{array}{c}\text { Standardized } \\
\text { coefficients }\end{array}$ & \multirow{2}{*}{$\mathrm{t}$} & \multirow{2}{*}{ Sig. } \\
\cline { 3 - 5 } & B & Std. error & Beta & & \\
\hline \multirow{2}{*}{1} & (Constant) & .514 & 1.064 & & .484 & .632 \\
\cline { 2 - 6 } & $\begin{array}{l}\text { Base } \\
\text { Salary }\end{array}$ & 1.71 & 3.540 & .762 & 5.22 & .00 \\
\cline { 2 - 5 } & $\begin{array}{l}\text { Share } \\
\text { Value }\end{array}$ & -8.62 & 3.268 & -.356 & -2.435 & .021 \\
\hline
\end{tabular}

Proposition (3): executive remuneration in the form of cash has an impact on risk-taking in the banking sector. The results in Table 3 indicate the Analysis of Variance (ANOVA). From the results in this Table, it becomes evident that, based on the particular data used, the base salary is a significant predictor of risk-taking in the form of Z-scores, with an F-value of 13.65, which is much larger than the critical F-value of 8.85 and a sig. value of 0.00 . Thus, Proposition (3) may be valid.

Proposition (4): an increase in executive remuneration in the form of cash leads to an increase in risk-taking. From the results indicated in Table 3, the nonstandardized coefficients for base salary are positive (1.71), which indicate that a higher base salary results in a higher Z-score and, thus, decreased risk-taking. This contradicts the theory, as the theory purports that an increase in base salary or in lucrative incentives would lead to an increase in risk-taking. As a result, Proposition (4) is not valid.

Proposition (5): executive incentives in the form of equity have an impact on risk-taking in the banking sector. Once again, from the results in Table 3, it becomes evident that the US\$ value of equity in the possession of an executive does have an impact on 
risk-taking, as measured in terms of Z-scores, with a pvalue of 0.021. Hence, Proposition (5) may be accepted.

Proposition (6): an increase in executive incentives in the form of equity value will lead to a decrease in risk-taking. From the results in the coefficient Table, it becomes clear that there is a negative relationship between the US\$ value in equity in possession of executives and the Z-scores (-8.62), which is contrary to the literature. Hence, Proposition (6) is not valid.

\section{Conclusion}

This research aimed to prove or disprove six propositions. Proposition (1): the health of the banking sector has significant effects on overall economic activity. Proposition (2): executive remuneration paid in cash decreased, while executive incentives in the form of equity increased post the credit crisis. Proposition (3): executive remuneration in the form of cash has an impact on risk-taking in the banking sector. Proposition (4): an increase in executive remuneration in the form of cash leads to an increase in risk-taking. Proposition (5): executive incentives in the form of equity have an impact on ris-taking in the banking sector. Proposition (6): an increase in executive incentives in the form of equity value will lead to a decrease in risk-taking.

In order to indicate the validity of Proposition (1), a literature review was conducted. It was proven by numerous studies that the sustainability of the banking industry was beneficial to the overall economy. In addition, due to the unique features of the banking sector, they, seldom if ever, function in isolation. This emphasizes the connectivity of the banking sector to most aspects of the broader economy. In addition, the dire repercussions of not only the credit crisis of 2007-2009, but also the Great Depression, evidenced the importance of the banking sector's sustainability.

In order to prove the validity of Proposition (2), descriptive statistics were analyzed, which indicated that executive remuneration increased, while equity in possession of executives decreased post the credit crisis.

Proposition (3) may be valid, based on the significance value obtained from data. The $p$-value was documented as 0.021 .

Proposition (4) was not validbased on the positive coefficient base salary. This indicated that, as remuneration in the form of cash increased, Z-scores also increased and hence, risk-taking decreased.

Proposition (5) may be valid, based on the significance value, which was 0.021 . This indicates that executive incentives in the form of equity did have an effect on the risk-taking levels of the banks in question. Proposition (6) was not valid, based on the negative coefficient share value. This indicates that, as equity value in the executives' possession increases, the Z-score will decrease and, hence, risktaking will increase.

In summary, the research points to the fact that executives have in fact been remunerated in terms of equity. However, the results indicate that this may not have enticed the executives to take on more risks. Even so, since there is con troversy regarding this matter, it is recommendedto link executive remuneration to debt. However, research has indicated that shareholders may not be able to commit to design compensation contracts in such a manner. The theme of executive remuneration, hence, remains one most definitely open for discussion and further research.

\section{References}

1. Afonso, G., Santos, J. \& Traina, J. (2014). Large and complex banks, Economic Policy Review, 20 (2), pp. 1-18.

2. Allen, F., Carletti, E. \& Marquez, R. (2014). Deposits and bank capital structure. Working paper. Available at: http://fic.wharton.upenn. Accessed: 22/04/2016.

3. Angeli, M. \& Gitay, S. (2015). Bonus regulation: aligning reward with risk in the banking sector, Quarterly Bulletin, 2015, Q4.

4. Armstrong, C.S., Larcker, D.F., Ormazabal, G. \& Taylor, D.J. (2013). The relation between equity incentives and misreporting: the role of risk-taking incentives, Journal of Financial Economics, 109 (2), pp. 327-350.

5. Bernanke, B. (1983). Non-monetary effects of the Financial Crisis in the propagation of the Great Depression, American Economic Review, 73, pp. 257-276.

6. Bolton, P., Mehran, H. \& Shapiro, J. (2015). Executive compensation and risk-taking, Review of Finance, 19, pp. 2139-2181.

7. Boyd, J.H., Graham, S.L. \& Hewitt, R.S. (1993). Bank holding company mergers with non-bank financial firms: effects on the risk of failure, Journal of Banking and Finance, 17 (1), pp. 43-63.

8. Chiaramonte, L., Croci, E. \& Poli, F. (2015). Should we trust the Z-score? Evidence from the European Banking Industry, Global Finance Journal, 25, 99, pp. 111-131.

9. Crawford, C. (2011). The repeal of the Glass Steagall Act and the current financial crisis, Journal of Business \& Economics Research, 9 (1), pp. 127-134.

10. Cunat, V.\& Guadalupe, M. (2009). Executive compensation and competition in the banking and financial sectors, Journal of Banking and Finance, 33, pp. 495-504. 
11. De Nicolo, G. (2000). Size, charter value and risk in banking: an international perspective. International Finance Discussion Papers No. 689, Washington, DC: Board of Governors of the Federal Reserve System. Available at: http://www.federalreserve.gov/pubs/ifdp/2000/689/default.htm. Accessed: 12/04/2016.

12. DeYoung, R., Pemg, E.Y. \& Yan, M. (2010). Executive compensation and policy choices at US commercial banks, Federal Reserve Bank of Kansas City Working Paper 10-02.

13. Erkens, D.H., Hung, M. \& Matos, P. (2012). Corporate governance in the 2007-2008 financial crisis: Evidence from financial institutions worldwide, Journal of Corporate Finance, 18 (2), pp. 389-411.

14. Falenbrach, R. \& Stulz, R. (2011). Bank CEO Incentives and the Credit Crisis, Journal of Financial Economics, 99 (1), pp. 11-26.

15. Ferrarini, G.A. \& Ungureanu, M.C. (2012). Bankers' pay after the 2008 crisis: regulatory reforms in the US and the EU, Journal of Banking Law and Banking, Available at: http://ssrn.com/abstract=2001492. Accessed: 26/04/2016.

16. Financial Stability Forum (FSF). (2009). FSF principles for sound compensation practices. Web: http://www.financial-stabilityboard.org. Accessed: 12/04/2016.

17. Gregg, P., Jewell, S. \& Tonks, I. (2012). Executive pay and performance: did bankers' bonuses cause the crisis? International Review of Finance, 12 (1), pp. 89-122.

18. Hagendorff, J. \& Vallascas, F. (2011). CEO pay incentives and risk-taking: evidence from bank acquisitions, Journal of Corporate Finance, 17(4), pp. 1078-1095.

19. Hannan, T.H. \& Hanweck, G.A. (1998). Bank solvency risk and the market for large certificates of deposit, Journal of Money, Credit, and Banking, 20 (2), pp. 203-211.

20. Jensen, M. and W. Meckling (1976). Theory of the Firm: Managerial Behavior, Agency Costs, and Ownership Structure, Journal of Financial Economics, 3, pp. 305-360.

21. Kalemli-Ozcan, S., Papaioannou, E. \& Peydro, J.L. (2013). Financial regulation, financial globalisation and synchronisation of economic activity, The Journal of Finance, 68 (3), pp. 1179-1228.

22. Keeley, M. (1990). Deposit insurance, risk, and market power in banking, American Economic Review, 80, pp. 1183-1200.

23. Kregel, J., Kottler, R. \& Tonveronachi, M. (2016). Financial Regulation in the EU. Routledge: Milton Park.

24. Leaven, L., Ratnovski, L. \& Tong, H. (2014). Bank size and systemic risk. Available at: https://www.imf.org/external/pubs/ft/sdn/2014/sdn1404.pdf. Accessed: 05/04/2016.

25. Liu, Z., Quiet, S. \& Roth, B. (2015). Banking sector interconnectedness: What is it, how can we measure it and why does it matter? Bank of England Quarterly Bulletin, 55, pp. 130-138.

26. Makinin, G.E. (2014). Money, banking, and economic activity. UK: Academic Press.

27. Merrouche, O. \& Nier, E. (2010). What caused the Global Financial Crisis? Evidence on the drivers of financial imbalances 1999-2007. IMF Working Paper, WP/10/265.

28. Mirzeai, A. (2013). Bank performance during the financial crisis 2007-2010, International Journal of Business and Economics, 12 (1), pp. 27-44.

29. Raviv, A. \& Sisli-Ciamarra, E. (2013). Executive compensation, risk-taking and the state of the economy, Journal of Financial Stability, 9 (1), pp. 55-68.

30. Rego, S.O. \& Wilson, R. (2012). Equity risk incentives and corporate tax aggressiveness, Journal of Accounting and Research, 50 (3), pp. 775-810.

31. Roy, A.D. (1952). Safety first and holding of assets, Econometrica, 20 (3), pp. 431-449.

32. Salehyan, I., Sirokey, D. \& Wood, R.M. (2014). External rebel sponsorship and civilian abuse: a principle agent analysis of wartime atrocities, International Organizations, 68 (3), pp. 633-661.

33. Smith, C.W. \& R. Stulz. (1985). The Determinants of Firms' Hedging Policies, Journal of Financial and Quantitative Analysis, 20, pp. 391-405.

34. Smith, C., Rotolo, A. \& Sartor, G. (2013). Reflex responsibility of agents. Available at: https://www.researchgate.net. Accessed: 26/04/2016.

35. Tarraf, H. \& Majeske, K. (2013). Impact of risk-taking on bank financial performance during 2008 financial crisis, Journal of Finance and Accountancy, 13, pp. 1-18.

36. Zalewska, A. (2015). A new look at regulating bankers' remuneration, Corporate Governance: An International Review, doi: 10.1111/corg.12149. 